\title{
The effect of obstructive sleep apnea syndrome on serum S100B and NSE levels: a systematic review and meta-analysis of observational studies
}

\author{
Farzad Rezaei ${ }^{1}$, Hooshyar Abbasi ${ }^{1}$, Masoud Sadeghi ${ }^{2,3}$ and Mohammad Moslem Imani ${ }^{4^{*}}$ (D)
}

\begin{abstract}
Background: Obstructive sleep apnea syndrome (OSAS) is a common disorder that is accompanied by structural brain changes. This meta-analysis aimed to evaluate the effect of OSAS on the serum levels of astrocytic protein (S100B) and neuron-specific enolase (NSE) in observational studies.

Methods: A comprehensive search was performed in the PubMed/Medline, Web of Science, Scopus, ScienceDirect, and Cochrane Library databases to assess the serum level of S100B and/or NSE in patients with OSAS and/or controls. The quality of the study was evaluated by the Newcastle-Ottawa Scale (NOS). A random-effects model was performed using RevMan 5.3 with the mean difference (MD) and 95\% confidence intervals (Cls).

Results: Out of 63 studies found in the mentioned databases and one identified by a manual search, nine studies were included and analyzed in this meta-analysis (three cross-sectional and six case-control studies). The analysis showed that the S100B $[\mathrm{MD}=53.58 \mathrm{pg} / \mathrm{ml}, 95 \% \mathrm{Cl}: 1.81,105.35 ; P=0.04]$ and NSE levels $[\mathrm{MD}=$ $3.78 \mathrm{ng} / \mathrm{ml}, 95 \% \mathrm{Cl}: 2.07,5.48 ; P<0.0001]$ were significantly higher in patients than the controls. However, there were no significant differences between the $\mathrm{S} 100 \mathrm{~B}[\mathrm{MD}=-28.00 \mathrm{pg} / \mathrm{ml}, 95 \% \mathrm{Cl}:-79.48,23.47 ; P=0.29]$ and NSE levels $[\mathrm{MD}=0.49 \mathrm{ng} / \mathrm{ml}, 95 \% \mathrm{Cl}:-0.82,1.80 ; P=0.46]$

Conclusions: This meta-analysis found elevated serum S100B and NSE levels in OSAS patients compared to the controls, which suggests that these markers may be used as peripheral indicators of brain damage in OSAS.
\end{abstract}

Keywords: Obstructive sleep apnea, Brain, Serum, S100b, NSE

\section{Background}

Obstructive sleep apnea syndrome (OSAS) is a common disease that manifests as repeated events of nighttime breathing cessation because of upper airway collapse [1]. Epidemiological studies have shown that OSAS has a high incidence in the general population, with a prevalence of $2-4 \%$ [2]. There is a correlation between OSAS and increased platelet adhesiveness, vascular endothelial dysfunction and

\footnotetext{
* Correspondence: mmoslem.imani@yahoo.com

${ }^{4}$ Department of Orthodontics, School of Dentistry, Kermanshah University of Medical Sciences, Kermanshah, Iran

Full list of author information is available at the end of the article
}

early symptoms of atherosclerosis, indicating an increased risk of vascular effects, such as stroke, in OSAS patients [3]. OSAS is accompanied by structural brain changes, and while how the brain is changed in OSAS remains unclear [4], OSAS likely causes brain injury [5]. Serum neuron-specific enolase (NSE) and astrocytic protein (S100B) concentrations have been examined under both clinical and experimental conditions to explain the relationship between neural cells and astrocytes in pathological situations [6, 7]. An elevated NSE level indicates neuronal injury, whereas an elevated S100B level may reflect either glial injury or astrocytic responses

(c) The Author(s). 2020 Open Access This article is distributed under the terms of the Creative Commons Attribution 4.0 International License (http://creativecommons.org/licenses/by/4.0/), which permits unrestricted use, distribution, and reproduction in any medium, provided you give appropriate credit to the original author(s) and the source, provide a link to the Creative Commons license, and indicate if changes were made. The Creative Commons Public Domain Dedication waiver (http://creativecommons.org/publicdomain/zero/1.0/) applies to the data made available in this article, unless otherwise stated. 
to neural damage [8]. These markers could serve as sensitive indicators of brain injury development [9]. The appearance of a biochemical marker of cerebral injury could serve as a considerable advantage in OSAS for identifying even small brain injuries and improving the efficacy of treatment [10].

The purpose of the present meta-analysis was to explore the effect of OSAS on serum S100B and NSE concentrations in observational studies.

\section{Methods}

This meta-analysis was done based on the guidelines for the Preferred Reporting Items for Systematic Reviews and Meta-Analyses (PRISMA) [11].

\section{Search strategies}

A comprehensive search was performed using the search terms "sleep apnea syndrome or apnea syndrome or sleep apnea or obstructive sleep or apnea syndrome or obstructive sleep apnea" and "S100B or astrocytic protein or NSE or neuron-specific enolase" in the PubMed/Medline, Web of Science, Scopus, ScienceDirect, and Cochrane Library databases without language restriction.

\section{Study selection}

Three authors were involved in the selection of studies. The first author (M.S.) searched the studies, and the second author (M.M.I.) was blinded to the findings of the first reviewer. Any disagreements between the two authors were resolved by the third author (F.R.). All articles in this study were examined for an evaluation of the serum level of S100B and/or NSE in patients with OSAS and/or controls. The studies included in this meta-analysis met the following inclusion criteria: a) case-control or cross-sectional design; b) human study; and c) included the serum level of S100B and/or NSE. The exclusion criteria were as follows: a) duplication of a previous publication; b) review or case-series; c) conference paper; d) no full text; and e) no relevant data.

\section{Data extraction}

Two authors (M.S \& F.R) checked the studies included in meta-analysis and extracted the relevant data. We extracted the author name, publication year, country, patient number, mean age, percentage of males, body mass index (BMI), apnea-hypopnea index (AHI), type of method, and method features in each group.

\section{Quality assessment}

The quality of the study was evaluated by the Newcastle-Ottawa Scale (NOS) [12]. One author (M.S) checked the quality of the studies. (The maximum total score was nine for case-control and cross-sectional studies. A high-quality study was considered a study with $\geq 7$ stars. The quality of each study was evaluated by two authors (M.S. and M.M.I.) who reached a consensus via discussion.

\section{Statistical analyses}

A random-effects model was used for analysis in Review Manager 5.3 (RevMan 5.3, The Cochrane Collaboration, Oxford, United Kingdom) using the mean difference (MD) and 95\% confidence intervals (CIs). The heterogeneity between estimations was calculated by the $\mathrm{Q}$ and $\mathrm{I}^{2}$ statistics. For the $\mathrm{Q}$ statistic, heterogeneity was considered for $P<0.1$. We graphically assessed publication bias using funnel plots and quantitatively evaluated bias using Begg's test and Egger's test in Comprehensive Meta-Analysis 2.0 as well as sensitivity analysis for evaluating the stability of the results using two strategies, the "cumulative analysis and one-study-removed". $P<0.05$ (two-sided) was considered statistically significant. The Wilcoxon test was used to compare the means among the OSAS severity grades. The units for S100B and NSE were pg/ $\mathrm{ml}$ and $\mathrm{ng} / \mathrm{ml}$, respectively. In some studies, we estimated the "median (quartile)," [13], "median (range)" [14] or "mean $( \pm \mathrm{SD})$." The pooled mean and SD were obtained by the $(\mathrm{N} 1 * \mathrm{M} 1+\mathrm{N} 2 * \mathrm{M} 2 / \mathrm{N} 1+\mathrm{N} 2)$ and $\left((\mathrm{N} 1-1)^{*} \mathrm{SD} 1+(\mathrm{N} 2-1)^{*} \mathrm{SD} 2 / \mathrm{N} 1+\mathrm{N} 2-2\right) \quad$ formulas described in "http://crtha.iums.ac.ir/files/crtha/files/ cochrane.pdf."

\section{Results}

A total of 63 studies were found in five databases. After removing duplicated studies, 31 articles were screened (Fig. 1). Out of the 31 studies screened, 21 articles were not relevant and therefore were excluded. Ten studies were evaluated for eligibility and one study identified by a manual search was added. Therefore, 11 studies were screened, 2 of which were excluded (one was an animal study and one did not report the relevant data). Finally, nine studies were included and analyzed in this meta-analysis.

Some characteristics of the studies included in the meta-analysis are shown in Table 1 . The studies were published from 2002 to 2017. Two studies were reported in Germany [10, 21], two in Brazil [15, 17], one in the Czech Republic [16], three in Turkey [1820], and one in Egypt [22]. Three were crosssectional studies $[10,16,17]$, and six were casecontrol studies $[15,18-22]$. Other information is shown in Table 1. 


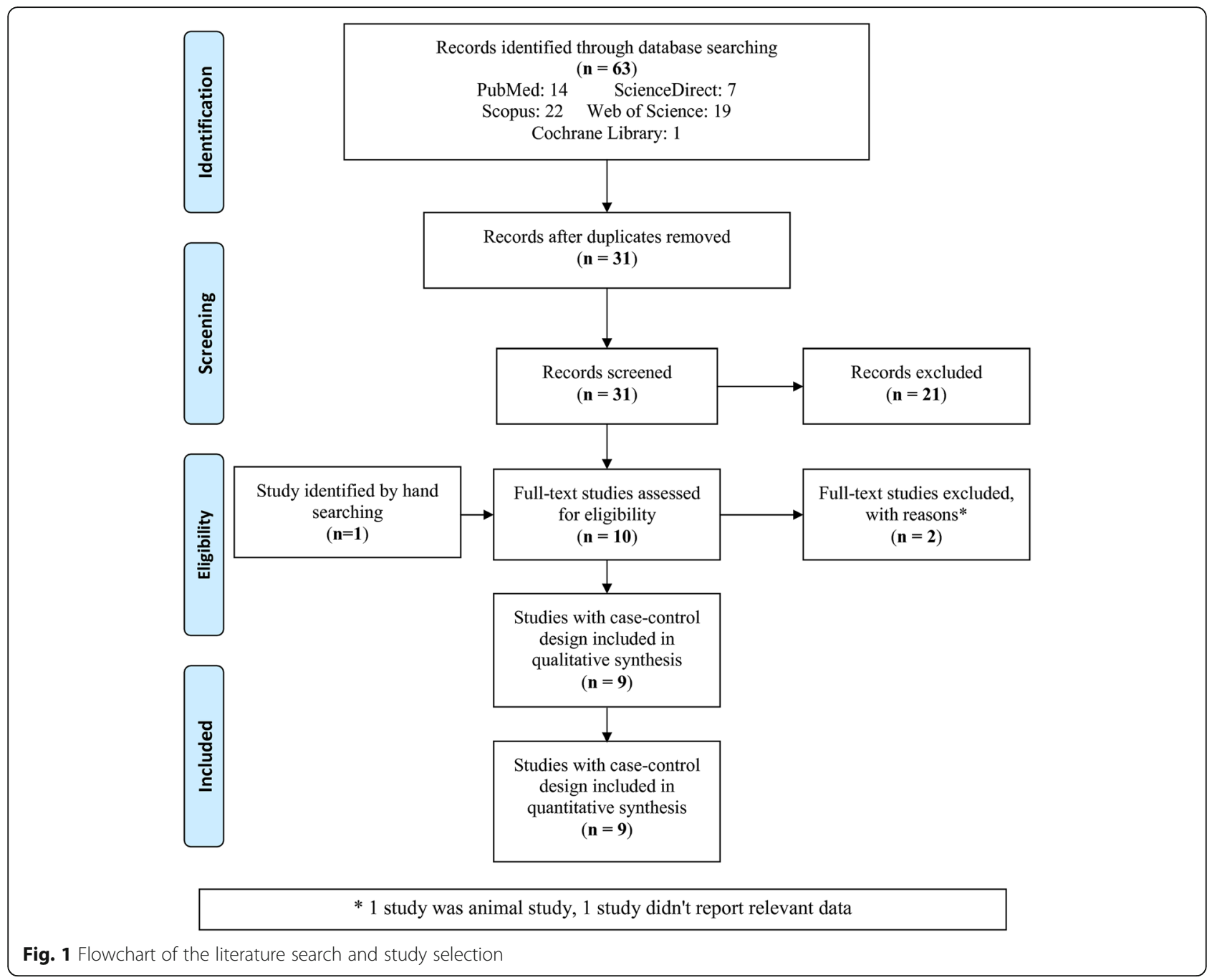

\section{Quality assessment}

Study-specific quality scores are summarized in Table 2. The mean score of the six case-control studies was 7.8. Four of them were awarded $\geq 7$ stars. The mean score of the three cross-sectional studies was 7 ; three studies were awarded $\geq 7$ stars and were defined as high-quality studies.

Figure 2 shows the pooled MD of the serum S100B and NSE levels in OSAS patients compared to controls. The analysis shows that the S100B $[\mathrm{MD}=53.58 \mathrm{pg} / \mathrm{ml}$, 95\%CI: $\left.1.81,105.35 ; P=0.04, I^{2}=98 \%(P<0.00001)\right]$ and NSE levels $[\mathrm{MD}=3.78 \mathrm{ng} / \mathrm{ml}, 95 \% \mathrm{CI}: 2.07,5.48 ; P<$ $\left.0.0001, I^{2}=0 \%(P=0.44)\right]$ were significantly higher in the patients than in the controls.

The pooled MD of the serum S100B and NSE levels in OSAS patients before and after sleep is shown in Fig. 3. There were no significant differences in the S100B $[\mathrm{MD}=-28.00 \mathrm{pg} / \mathrm{ml}, 95 \% \mathrm{CI}$ : $\left.79.48,23.47 ; P=0.29, I^{2}=67 \%(P=0.08)\right]$ or NSE level $[\mathrm{MD}=0.49 \mathrm{ng} / \mathrm{ml}, 95 \% \mathrm{CI}:-0.82,1.80 ; P=0.46$, $\left.I^{2}=0 \%(P=0.41)\right]$.

Three studies $[19,21,22]$ divided the severity of OSAS into three groups based on the AHI (mild, moderate, and severe). A comparison of the mean S100B level among these groups is shown in Table 3; no significant differences were found $(P>0.05)$.

\section{Publication bias}

Among the subgroup analysis, only one subgroup included more than two studies, allowing us to measure publication bias (S100B level in the patients compared to the controls) (Fig. 4). The points indicating the individual studies have a symmetric funnel plot and are distributed about the mean effect across the spectrum of precision levels and therefore Begg's and Egger's tests did not reveal the significant evidence of publication bias across the included studies. 


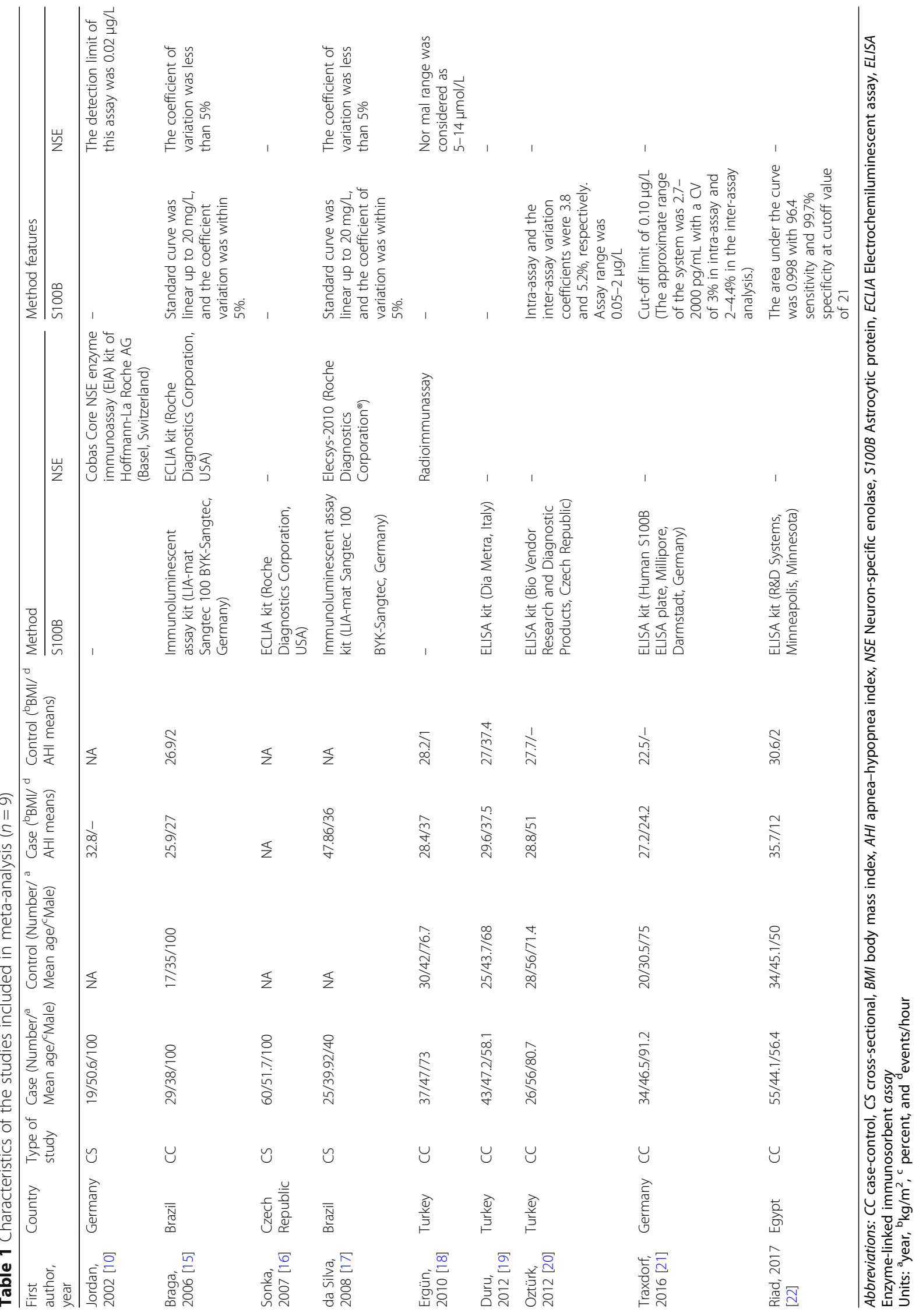


Table 2 Quality ratings for the studies included on the basis of Newcastle-Ottawa quality assessment scale $(n=9)$

\begin{tabular}{lllll}
\hline First author, year & Selection & Comparability & Outcome & Total score \\
\hline Braga, 2006 [15] & 3 & 1 & 2 & 6 \\
Ergün, 2010 [18] & 3 & 2 & 2 & 7 \\
Duru, 2012 [19] & 3 & 2 & 2 & 7 \\
Oztürk, 2012 [20] & 4 & 2 & 2 & 8 \\
Traxdorf, 2016 [21] & 3 & 1 & 2 & 6 \\
Riad, 2017 [22] & 3 & 2 & 2 & 7 \\
Mean score (case-control studies) & & 7.8 \\
Jordan, 2002 [10] & 3 & 2 & 2 & 7 \\
Sonka, 2007 [16] & 3 & 2 & 2 & 7 \\
da Silva, 2008 [17] & 3 & 2 & 2 & 7 \\
Mean score (cross-sectional studies) & & 7
\end{tabular}

\section{Sensitivity analysis}

Both strategies- one study excluded" and "cumulative analysis"- were performed on an analysis with minimum three studies (S100B level in the patients compared to the controls) and did not qualitatively change the pooled OR. Therefore, these strategies revealed that the pooled OR was stable.

\section{Discussion}

The meta-analysis evaluated serum S100B and NSE markers related to brain damages in OSAS patients. It was observed that serum levels of these markers in the patients were significantly higher than the controls, but the level changes were no significant after compared to before sleep.
OSAS can be related to cardiovascular and metabolic disorders, high blood pressure, diabetes, obesity, coronary artery illness [23, 24], stroke, and heart failure $[25,26]$. OSAS can also cause cellular injury in the central nervous system (CNS) [27]. This metaanalysis shows that the serum S100B and NSE concentrations were significantly elevated in OSAS patients compared with the controls but that no significant changes occurred in the serum S100B and NSE levels of the patients during sleep. In addition, the S100B level was not significantly correlated with OSAS severity. Several studies [15, 19-22] reported higher serum S100B levels in OSAS patients than in the controls, indicating a significant difference in four studies $[15,19,21,22]$. Two studies [15, 18] showed that the serum NSE level was significantly in OSAS patients higher than in the controls. The study by da Silva et al. [17] showed a significant difference in the serum S100B level after sleep compared with before sleep in the patients, but this difference was not confirmed by Sonka et al. [16]. In addition, two studies $[10,17]$ showed no significant difference in the serum NSE level after sleep compared to before sleep in the patients. In three studies [19, 21, 22] that assessed the S100B level in OSAS patients based on severity grade, there was no significant correlation between the S100B level and OSAS severity.

Studies of the cerebrospinal fluid (CSF) levels of S100B and NSE in patients with neurological injuries have shown a quantitative correlation between the degree of cell damage in the CNS and the level of these markers in CSF [28]. Clinically, elevated levels of NSE and S100B protein have been observed early following

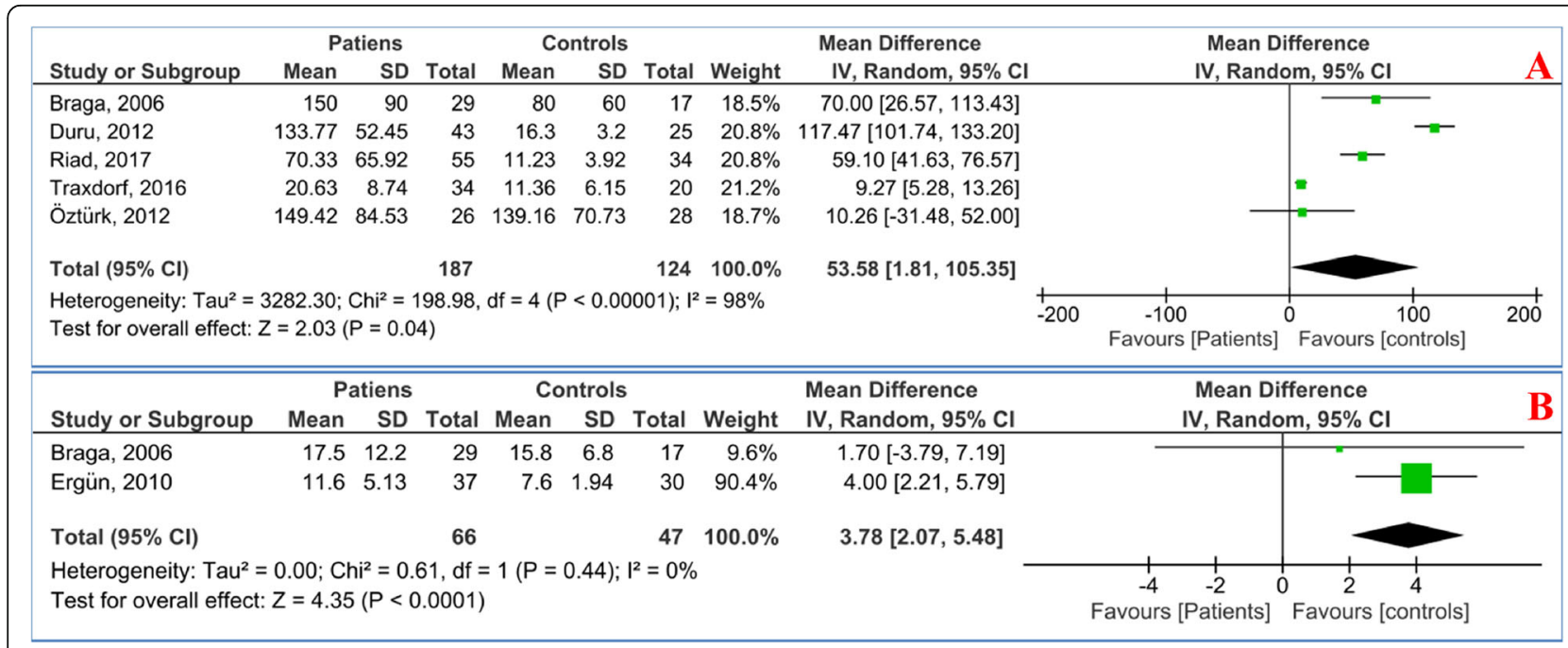

Fig. 2 Forest plot of the random effects of the serum a S100B and $\mathbf{b}$ NSE levels in patients with OSAS compared to controls 


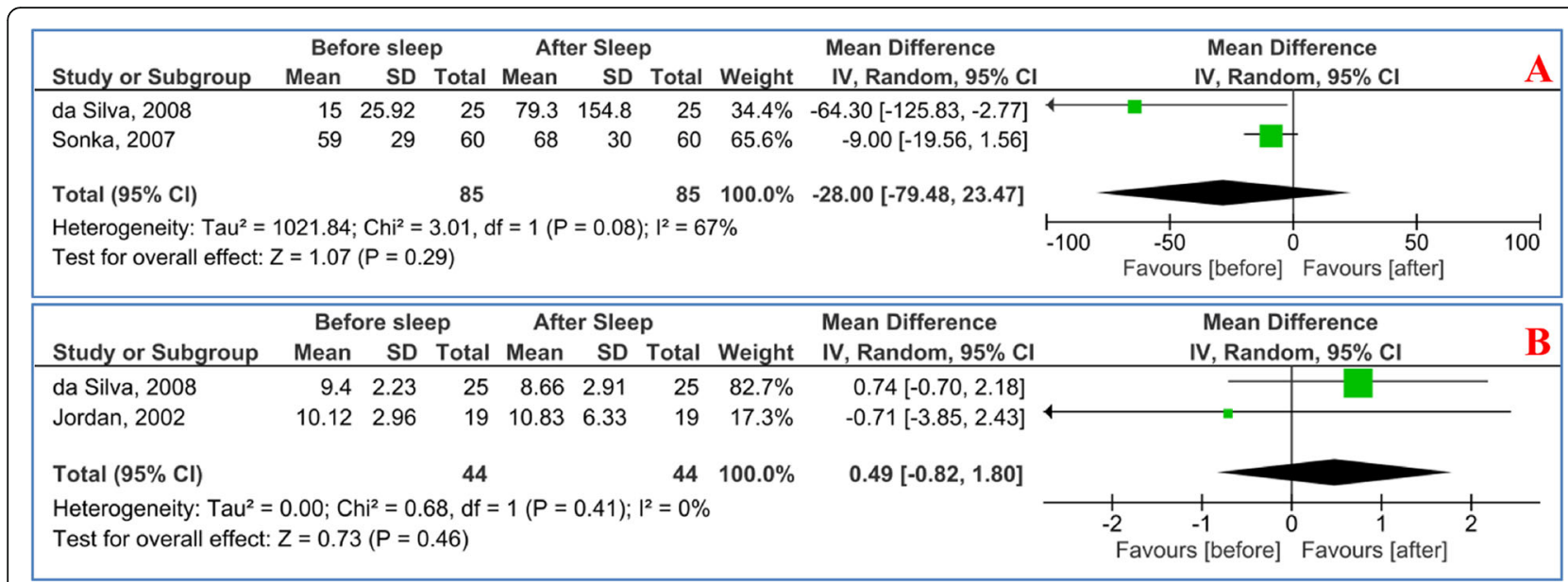

Fig. 3 Forest plot of the random effects of the serum a S100B and $\mathbf{b}$ NSE levels in patients with OSAS before and after sleep

ischemic stroke, and elevated levels of S100B protein have been observed after intracerebral and subarachnoid hemorrhage [29]. The serum S100B level may increase not only due to glial injury but merely by opening the blood-brain barrier [30]. Cerebrovascular and neuropsychiatric disorders [31, 32], trauma, and stroke [33] can cause increased serum S100B protein levels due to $\mathrm{S100B}$ release from astrocytes.

In patients with mild and severe OSAS without neurological signs or a history of cerebrovascular events, there were no elevations in the serum NSE or S100B level [10]. da Silva et al. [17] reported a correlation between depression and elevated S100B levels in unhealthy obese patients. In addition, older patients are more likely to experience brain injury due to OSAS than younger patients [16]. It also appears that serum S100B levels are not dependent on age or sex $[19,34]$. Duru et al. [19] reported no significant relationship between the serum S100B level and related factors of OSAS, including the AHI and patient characteristics, such as age and BMI. However, Sonka et al. [16] showed that the serum S100B

Table 3 Comparison of serum S100B levels and severity of obstructive sleep apnea syndrome

\begin{tabular}{llll}
\hline First author, year & Mild $(n=13)$ & Moderate $(n=21)$ & Severe $(n=9)$ \\
Duru, 2012 [19] & $126.67 \pm 55.97$ & $134.32 \pm 61.55^{\mathrm{a}}$ & $138.79 \pm 58.83^{\mathrm{ab}}$ \\
& Mild $(n=5)$ & Moderate $(n=15)$ & Severe $(n=14)$ \\
Traxdorf, 2016 [21] & $16.9 \pm 5.26$ & $21.5 \pm 7.18^{\mathrm{a}}$ & $20.37 \pm 12.15^{\mathrm{ab}}$ \\
& Mild $(n=32)$ & Moderate $(n=14)$ & Severe $(n=7)$ \\
Riad, 2017 [22] & $67.66 \pm 53.3$ & $60.5 \pm 68.51^{\mathrm{a}}$ & $91 \pm 96.5^{\mathrm{ab}}$ \\
\hline
\end{tabular}

${ }^{a}$ Wilcoxon test: $P>0.05$ compared to mild. ${ }^{\mathrm{b}}$ Wilcoxon test: $P>0.05$ compared to moderate concentration was inversely related to the AHI and directly related to both the basal and mean minimal oxygen saturation $(\mathrm{SaO} 2)$ in line to the results of Riad's study [22]. It has been confirmed that low mean nighttime $\mathrm{SpO}_{2}$ significantly associated with an elevated risk of a central nervous system events [35]. In OSAS patients, there is main effect of BMI on S100B level [22]. Duru et al. [19] reported that serum S100B levels did not correlate with age and BMI. Another study [36] showed that there is a negative correlation between serum S100B level and age in patients below 20 years, but after 20 years, S100B level has not appear to vary with age. Braga et al. [15] found a mild effect of age on S100B level, whereas Riad et al. [22] didn't find any correlation between them. The studies checking $\mathrm{SaO} 2$ in OSAS patients compared to the controls showed that S100B $[15,16]$ and NSE [15] levels had no significant correlation with minimum $\mathrm{SaO} 2$ levels. Another study [17] showed a negative correlation between S100B levels and minimum $\mathrm{SaO} 2$ levels. Despite a few reported studies, S100B or NSE levels can be correlated with age, sex, AHI, and $\mathrm{SaO} 2$ levels. The studies reported different assay methods for S100B and NSE that some methods had a poor inter-assay that it can lead to inconsistent results [21] and reduce the reliability of results of the studies included in the meta-analysis. Therefore, it needs more studies in the future to confirm the effect of S100B or NSE levels on OSAS using unit methods for increasing the accuracy and reliability of the results.

The limitations of the study included the few studies in each analysis and differences among the studies in terms of age, sex, BMI, AHI, and different methods (different cut-offs or inter-assay). 


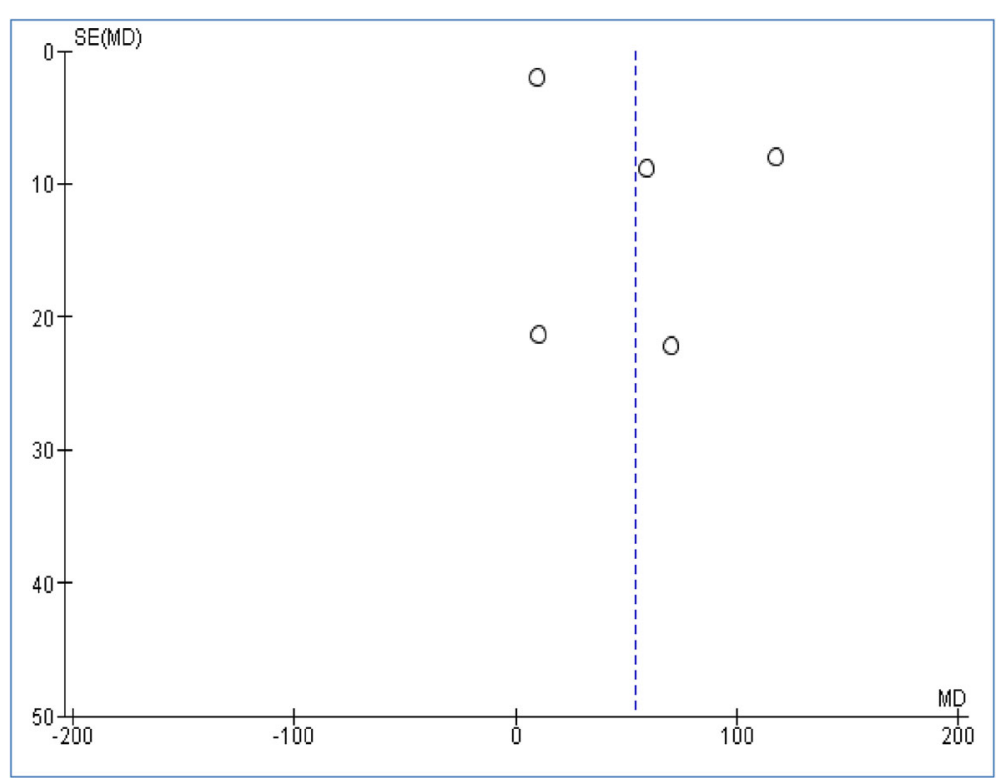

Fig. 4 Funnel plot of the random effects of the serum S100B level in patients with OSAS compared to controls

\section{Conclusions}

This meta-analysis found elevated serum S100B and NSE levels in OSAS patients compared to controls, which suggests that these markers could be used as peripheral indicators of brain damage in OSAS. Regarding the low number of the studies, the pooled analysis showed no significant correlation between the S100B level and OSAS severity or a difference in the S100B or NSE level after sleep compared to before sleep in the patients. Therefore, more case-control or cross-sectional studies are needed with an emphasis on demographic factors to confirm the results of this meta-analysis.

\section{Abbreviations}

AHI: Apnea-hypopnea index; BMI: Body mass index; Cl: Confidence interval; MD: Mean difference; NOS: Newcastle-Ottawa Scale; NSE: Neuron-specific enolase; OSAS: Obstructive sleep apnea syndrome; S100B: Astrocytic protein

\section{Acknowledgments}

Not applicable.

\section{Authors' contributions}

FR designed the manuscript. MS collected and analyzed the data. MM drafted the manuscript and approved its submission. HA, MS and MMI checked eligibility of the studies included in meta-analysis. MS checked the quality of the studies. FR and HA critically revised the manuscript. All authors have read and approved the final manuscript.

\section{Funding}

Not applicable.

\section{Availability of data and materials}

The datasets used and/or analysed during the current study available from the corresponding author on reasonable request.

Ethics approval and consent to participate Not applicable.

\section{Consent for publication}

Not applicable.

\section{Competing interests}

The authors declare that they have no competing interests.

\section{Author details}

'Department of Oral and Maxillofacial Surgery, Kermanshah University of Medical Sciences, Kermanshah, Iran. ${ }^{2}$ Medical Biology Research Center, Kermanshah University of Medical Sciences, Kermanshah, Iran. ${ }^{3}$ Students Research Committee, Kermanshah University of Medical Sciences, Kermanshah, Iran. ${ }^{4}$ Department of Orthodontics, School of Dentistry, Kermanshah University of Medical Sciences, Kermanshah, Iran.

Received: 13 May 2018 Accepted: 27 January 2020

Published online: 05 February 2020

\section{References}

1. Guilleminault C, Quo SD. Sleep-disordered breathing. A view at the beginning of the new millennium. Dent Clin N Am. 2001;45(4):643-56.

2. Ferini-Strambi L, Fantini ML. Cerebrovascular diseases and sleep-disordered breathing. Clin Exp Hypertens. 2006;28:225-31.

3. Drager LF, Bortolotto LA, Lorenzi MC, Fiqueiredo AC, Krieger EM, LorenziFilho G. Early signs of atherosclerosis in obstructive sleep apnea. Am J Respir Crit Care Med. 2005;172:613-8.

4. Macey PM. Is brain injury in obstructive sleep apnea reversible? Sleep. 2012; 35:9-10.

5. O'Donoghue FJ, Wellard RM, Rochford PD, et al. Magnetic resonance spectroscopy and neurocognitive dysfunction in obstructive sleep apnea before and after CPAP treatment. Sleep. 2012;35:41-8.

6. Mazzini G, Schaf D, Oliveira AR, Goncalves CA, Souza DO, Portela LV. The ischemic rat heart releases S100B. Life Sci. 2005;77:882-9.

7. Willoughby KA, Kleindienst A, Müller C, Chen T, Muir JK, Ellis EF. S100B protein is released by in vitro trauma and reduces delayed neuronal injury. J Neurochem. 2004;91:1284-91.

8. Herrmann M, Vos P, Wunderlich MT, de Bruijn CH, Lamers KJ. Release of glial tissue-specific proteins after acute stroke: a comparative analysis of serum concentrations of protein S-100B and glial fibrillary acidic protein. Stroke. 2000;31:2670-7.

9. Hajduková L, Sobek O, Prchalová D, Bílková Z, Koudelková M, Lukášková J, et al. Biomarkers of brain damage: S100B and NSE concentrations in cerebrospinal fluid--a normative study. Biomed Res Int. 2015;2015:379071. 
10. Jordan W, Hagedohm J, Wiltfang J, Laier-Groeneveld G, Tumani H, Rodenbeck A, et al. Biochemical markers of cerebrovascular injury in sleep apnoea syndrome. Eur Respir J. 2002;20:158-64.

11. Moher D, Liberati A, Tetzlaff J, Altman DG, PRISMA Group. Preferred reporting items for systematic reviews and meta-analyses: the PRISMA statement. PLoS Med. 2009:6:e1000097.

12. Wells GA, Shea B, O'Connell D, Peterson J, Welch V, Losos M, et al. The Newcastle-Ottawa scale (NOS) for assessing the quality of nonrandomised studies in meta-analyses. Ottawa: Ottawa Hospital Research Institute; 2011. http://www.ohri.ca/programs/clinical_epidemiology/ oxford.asp. Accessed 12 Jan 2016

13. Wan X, Wang W, Liu J, Tong T. Estimating the sample mean and standard deviation from the sample size, median, range and/or interquartile range. BMC Med Res Methodol. 2014;14:135.

14. Hozo SP, Djulbegovic B, Hozo I. Estimating the mean and variance from the median, range, and the size of a sample. BMC Med Res Methodol. 2005;5:13.

15. Braga CW, Martinez D, Wofchuk S, Portela LV, Souza DO. S100B and NSE serum levels in obstructive sleep apnea syndrome. Sleep Med. 2006;7:431-5

16. Sonka K, Kelemen J, Kemlink D, Volná J, Pretl M, Zima T, et al. Evening and morning plasma levels of protein S100B in patients with obstructive sleep apnea. Neuro Endocrinol Lett. 2007;28:575-9.

17. da Silva LG, Mottin CC, Souza DO, Portela LV, Braga CW, Vargas CB, et al. Serum S100B but not NSE levels are increased in morbidly obese individuals affected by obstructive sleep apnea-hypopnea syndrome. Obes Surg. 2008; 18:993-9.

18. Ergün $P$, Çiftçi $B$, Ergün $R$, Erdoğan $Y$, Turay UY, Biber $C$, et al. Serum neuronspecific enolase. (nse) and homocysteine levels in obtructive sleep apnea syndrome. Turkiye Klinikleri J Med Sci. 2010;30:1884-90.

19. Duru S, Hikmet Fırat I, Colak N, Giniş Z, Delibaşı T, Ardıç S. Serum S100B protein: a useful marker in obstructive sleep apnea syndrome. Neurol Neurochir Pol. 2012:46(5):450-5

20. Öztürk G, Giniş Z, Arlı B, Bilen Ș, Erden G, Ulusoy E, Züngün C. Serum S100B levels in patients with obstructive sleep apnea syndrome. J Clin Exp Invest. 2012;3:345-9.

21. Traxdorf M, Wendler O, Tziridis K, Bauer J, Scherl C. S100B in serum and saliva: a valid invasive or non-invasive biomarker in obstructive sleep apnea? Eur Rev Med Pharmacol Sci. 2016;20:4766-74.

22. Riad E, Nasser M, Hussein MH, Toraih EA, Fawzy MS. Serum S100B: a possible biomarker for severity of obstructive sleep apnea. Egypt J Chest Dis Tuberc. 2017;66:639-43.

23. Fritscher LG, Mottin CC, Canani S, Chatkin JM. Obesity and obstructive sleep apnea-hypopnea syndrome: the impact of bariatric surgery. Obes Surg. 2007;17:95-9.

24. Giunta J, Salifu M, McFarlane S. Sleep disorders and cardio-renal disease: implications for minority populations. Epidemiology. 2016;6: e120.

25. Yaggi HK, Concato J, Kernan WN, Lichtman JH, Brass LM, Mohsenin V. Obstructive sleep apnea as a risk factor for stroke and death. N Engl J Med. 2005;353:2034-41.

26. Kaneko Y, Floras JS, Usui K, Plante J, Tkacova R, Kubo T, et al. Cardiovascular effects of continuous positive airway pressure in patients with heart failure and obstructive sleep apnea. N Engl J Med. 2003;348: $1233-41$.

27. Bartlett DJ, Rae C, Thompson CH, Byth K, Joffe DA, Enright T, et al. Hippocampal area metabolites relate to severity and cognitive function in obstructive sleep apnea. Sleep Med. 2004;5:593-6.

28. Hrdemark HG, Ericsson N, Kotwica Z, Rundstrm G, Mendel-Hartvig I, Olsson $Y$, et al. S-100 protein and neuron-specific enolase in CSF after experimental traumatic or focal ischemic brain damage. J Neurosurg. 1989;71:727-31.

29. Missler U, Wiesmann M, Friedrich C, Kaps M. S-100 protein and neuronspecific enolase concentrations in blood as indicators of infarction volume and prognosis in acute ischemic stroke. Stroke. 1997;28:195660 .

30. Marchi N, Cavaglia M, Fazio V, Bhudia S, Hallene K, Janigro D. Peripheral markers of blood-brain barrier damage. Clin Chim Acta. 2004:342:1-12.

31. Gale SD, Hopkins RO. Effects of hypoxia on the brain: neuro - imaging and neuropsychological findings following carbon mono - xide poisoning and obstructive sleep apnea. J Int Neuropsychol Soc. 2004;10: 60-71.

32. Hu J, Ferreira A, Van Eldik L. S100beta induces neuronal cell death through nitric oxide release from astrocytes. J Neurochem. 1997:69:2294-301.

33. Ettinger A, Laumark AB, Ostroff RM, Brundell J, Baumgartner WA, Razumovsky AY. A new optical immunoassay for detection of S-100B protein in whole blood. Ann Thorac Surg. 1999;68:2196-201.

34. Wiesmann M, Missler U, Gottmann D, Gehring S. Plasma S-100b protein concentration in healthy adults is age- and sex-independent. Clin Chem. 1998:44:1056-8.

35. Kirkham FJ, Hewes DKM, Prengler M, Wade A, Lane R, Evans JP. Nocturnal hypoxaemia and central-nervous-system events in sickle-cell disease. Lancet. 2001;357:1656-9.

36. Portela LV, Tort AB, Schaf DV, Ribeiro L, Nora DB, Walz R, et al. The serum S100B concentration is age dependent. Clin Chem. 2002;48:950-2.

\section{Publisher's Note}

Springer Nature remains neutral with regard to jurisdictional claims in published maps and institutional affiliations.

Ready to submit your research? Choose BMC and benefit from:

- fast, convenient online submission

- thorough peer review by experienced researchers in your field

- rapid publication on acceptance

- support for research data, including large and complex data types

- gold Open Access which fosters wider collaboration and increased citations

- maximum visibility for your research: over $100 \mathrm{M}$ website views per year

At BMC, research is always in progress.

Learn more biomedcentral.com/submissions 